\title{
Yumurtacı Tavuk Rasyonlarına Katılan Organik Asitlerin Performans, Yumurta Kalitesi ve Bazı Kan Parametreleri Üzerine Etkisi
}

\author{
Çimen SARI, Adem KAYA* \\ Atatürk Üniversitesi Ziraat Fakültesi Zootekni Bölümü, 25240-Erzurum \\ *İletişim (correspondence): e-posta: akaya @ atauni.edu.tr; Tel: +90 (442) 2311397; Faks: +90 (256) 7117054 \\ Gönderim tarihi (Received): 03 Ekim 2017; Kabul tarihi (Accepted): 13 Kasım 2017 \\ ** Bu çalışma Çimen Sarı’ nın Yüksek Lisans Tezinden üretilmiştir.
}

\section{$\ddot{O} z$}

$\mathrm{Bu}$ çalı̧ma, yumurtacı tavuk rasyonlarına ilave edilen bazı organik asitlerin (propiyonik, formik ve malik Asit) yumurtlama performansı, yumurta kalitesi ve bazı kan parametreleri üzerine etkilerinin incelemek amacıyla yürütülmüştür. Araştırmada, toplam 96 adet 28 haftalık Lohmann (LSL) beyaz yumurtacı tavuk kullanılmıştır. Deneme hayvanları her biri altı alt gruptan ve her alt grupta dört hayvan olacak şekilde bir kontrol ve üç muamele grubuna şansa bağlı olarak dağtılımıştır. Kontrol grubundaki hayvanlar bazal yemle, muamele grupları ise bazal yeme sırasıly $200 \mathrm{mg} / \mathrm{kg}$ propiyonik asit (PA), formik asit (FA) ve malik asit (MA) ilave edilerek hazırlanan rasyonlarla 13 hafta süreyle beslenmiştir. Yumurtacı tavuk rasyonlarına ilave edilen farklı organik asitlerin yumurtlama performansı üzerine etkisi önemsiz bulunmuştur $(\mathrm{P}>0.05)$. PA grubundan elde edilen yumurtaların kabuk kalınlı̆ı̆, FA grubundakilerden daha yüksek olmuş̧ur $(\mathrm{P}<0.05)$. İncelenen diğer yumurta kalite kriterleri bakımından gruplar arasında herhangi bir farkın olmadığ tespit edilmiştir $(\mathrm{P}>0.05)$. PA grubundaki hayvanlarda kan $\mathrm{Ca}$ ve $\mathrm{P}$ içerikleri kontrol ve $\mathrm{FA}$ grubundan daha yüksek bulunmuş̧ur. Diğer kan parametrelerine (Kolesterol, Glukoz, ALP, ALT, AST) ait değerler bakımından gruplar arasındaki farklılıkların önemli olmadı̆

Anahtar kelimeler: Yumurtacı tavuk, organik asit, performans, yumurta kalitesi, kan parametreleri

\section{Effect of Organic Acids Supplemented Into Diet of Laying Hens on Performance, Egg Quality Traits and Some Blood Parameters}

\begin{abstract}
The present investigation was conducted out to study the effects of different organic acids supplemented (propionic acid, formic acid and malic acid) into diet of hens on performance, egg quality features and some blood parameters. This study consisted of a total of 96, 28-week-old, Lohmann White laying hens. Layers were randomly distributed into four experimental groups. Each experimental group of six replicates of four birds each was fed with diets containing a standart commercial layer diet (Control, C), basal diet $+200 \mathrm{mg} / \mathrm{kg}$ propionic acid(PA), basal diet + formic acid(FA) and basal diet + malik acid(MA). Present study lasted for 13 weeks. The different organic acid supplementation into laying hens diets had no significant effect on laying performance. Egg shell thickness determined for in PA group was higher than that of FA group. The other egg quality traits were not affected by organic acid supplementation into layer diet. Propionic acid supplemantation into laying hen diet increased serum $\mathrm{Ca}$ and $\mathrm{P}$ levels compared with control and FA groups $(\mathrm{P}<0.05)$. Other blood parameters such as ALP, ALT, AST, cholesterol and glucose did not affected by the organic acid supplementation $(\mathrm{P}>0.05)$.
\end{abstract}

Keywords: Laying hen, organic acid, performance, egg quality, blood parameters

\section{Giriş}

Kimyasal yapıları karbon iskeletine dayalı olan tüm asitler organik ya da karboksilik asitler olarak adlandırılmaktadır (Kum ve Güçlü, 2006). Saf olarak bitkisel ve hayvansal organizmada bulunabilmelerinin yanında doğal yollardan da elde edilebilirler. Organizmada sağlık sorunu ve risk oluşturabilecek bir kalıntı bırakmazlar. Tüm dünyada karma yem üretiminde ve hayvan beslemede koruyucu ve verim artırıcı olarak kullanılmaktadırlar (Anonim, 2014). Organik asitler kaba yem ve karma yem üretiminde yemlerin bozulmasını önlemekle birlikte (Kaya ve ark. 2012) yemlerin depolanması ve hayvanların verimliliğini artırmasındaki önemli katkılarından dolayı hayvan beslemede önemleri büyüktür. Organik asitler yemdeki asitliliği artırarak lezzetliliği ve yem tüketimini (Kahraman ve ark. 2009; Yeşilbağ ve Çolpan 2003) ve asit anyonlarının Ca, P, Mg ve $\mathrm{Zn}$ ile bileşikler oluşturarak bu minerallerin 
sindirimini kolaylaştırdıkları bildirilmektedir (Gauther, 2002). Organik asitlerin kanatlllarda immun sistemi geliştirici özelliğinin de olduğu bildirilmektedir (Abdel. Fattah, 2008).

Günümüzde, yaklaşık olarak 60 adet organik asit (fumarik asit, malik asit, sitrik asit formik asit vb gibi) tanımlanmış (Park et al. 2009) olmasına karşın, hayvan besleme ve karma yem endüstrisinde propiyonik asit en çok kullanılanlar arasındadır. Propiyonik asit keskin bir kokuya sahip, deri ile temasında tahrişlere sebep olabilen kuvvetli bir asittir. Sodyum ve kalsiyum propiyonatları esas olarak firıncılık ürünlerinde küf ve rope önleyici (inhibitörü), peynir teknolojisinde küf önleyici ve emülgatör olarak, kalsiyum tuzu da ekmek hamurunu kuvvetlendirmek için kullanılmaktadır.

Formik asit, kimyasal formülü $\mathrm{HCOOH}$ olan tek karbonlu karboksilik bir asittir. Formik asit tekstil sektöründe, boyama işlemlerinde, çamaşır temizleme fabrikalarında, zirai mücadele ilaçlarının üretiminde, hayvan derisi işleme, tabaklama ve tüy temizleme işlemlerinde, tıpta lokal anestezilerde, ekmek mayası üretiminde ve ayna üretimi gibi değişik alanlarda kullanılır. Malik asit, birçok meyve ve sebzede doğal olarak bulunduğu için diğer bir adı da meyve asididir. Düzgün ve mayhoş bir lezzete sahiptir. Sitrik asitten daha güçlü bir asidik tadı vardır. Bazı gıdalarda sitrik aside benzer tat bırakırlar. Bazı gıdalarda ise doğal lezzet algısı ve etkisi yaratırlar. Bu özellikleri nedeniyle malik asitler pek çok endüstri dalında farklı amaçlarla yoğun biçimde kullanılırlar.
$\mathrm{Bu}$ çalışma, bir ticari firmadan temin edilen propiyonik, formik ve malik organik asitlerinin pik dönemdeki yumurtacı tavuk rasyonlarına ilavesinin performans, yumurta kalite özellikleri ve bazı önemli kan parametreleri üzerine etkisinin belirlenmesi amacıyla yürütülmüştür.

\section{Materyal ve Yöntem}

$\mathrm{Bu}$ çalışmada, hayvan materyali olarak 96 adet tüm aşıları yapılmış olan 28 haftalık yaştaki Lohmann (LSL) tipi beyaz yumurtacı tavuk, her biri 6 alt gruptan oluşan biri kontrol olmak üzere toplam dört gruba ayrılarak, tavuklar, her bir kafeste 4 tane olacak şekilde tam şansa bağlı deneme desenine göre üç katlı batarya tipi kafeslere $(46 * 46 * 50 \mathrm{~cm})$ yerleştirilmişlerdir.

Birinci grup besin madde kompozisyonu Çizelge 1'de verilen bazal yemle (Kontrol), diğer deneme grupları ise bazal yeme $200 \mathrm{mg} / \mathrm{kg}$ düzeylerinde propiyonik asit (PA), formik asit (FA) ve malik asit (MA) ilaveleriyle oluşturulan rasyonlarla 1 haftası deneme yemlerine alıştırma periyodu olmak üzere toplam 13 hafta süreyle beslenmişlerdir. Çalışmada kullanılan bazal yemin kuru madde (KM), ham protein (HP), ham yağ (HY), ham selüloz (HS) ve ham kül (HK) içerikleri Weende analiz yöntemine göre AOAC (1990)'nin bildirdiği gibi belirlenmiştir. Yem ve su ad-libitum olarak verilmiş, deneme kümesinde 17 saatlik aydınlatma programı uygulanmıştır.

Çizelge 1. Bazal Yemin Bileşimi ve Kimyasal Kompozisyonu

\begin{tabular}{|c|c|c|c|c|}
\hline \multirow[t]{2}{*}{ Yem Hammaddeleri } & \multirow{2}{*}{$\begin{array}{c}\% \\
59.63 \\
\end{array}$} & \multicolumn{3}{|c|}{ Kimyasal Kompozisyon (\%) } \\
\hline & & KM, en az & & 88.00 \\
\hline Soya (\%46 HP) & 19.50 & $\mathrm{HP}$, en az & & 15.00 \\
\hline Ayçiçeği Küspesi (\%36 HP) & 7.40 & HS, en fazla & & 7.00 \\
\hline Soya Yağ1 & 1.49 & HY, en fazla & & 4.00 \\
\hline Et- Kemik Unu & 1.50 & HK, en fazla & & 14.00 \\
\hline Monokalsiyum Fosfat & 0.07 & $\mathrm{Ca}$, en az- en çok & & $3.00-4.00$ \\
\hline Mermer Tozu & 9.50 & $\mathrm{P}$, en az & & 0.70 \\
\hline Vitamin- mineral premiks ${ }^{1}$ & 0.30 & $\mathrm{ME}(\mathrm{kcal} / \mathrm{kg})$ & & 2750 \\
\hline Tuz & 0.20 & & & \\
\hline Sodyum Bikarbonat & 0.15 & & & \\
\hline Ekobond & 0.10 & & & \\
\hline Salmonil LCT & 0.10 & & & \\
\hline Metiyonin $^{2}$ & 0.06 & & & \\
\hline \multicolumn{5}{|c|}{ Analizle Belirlenen Kimyasal Kompozisyon } \\
\hline KM (\%) & HS (\%) & HY $(\%)$ & HK (\%) & $\mathrm{ME}^{3}$ (kcal/kg) \\
\hline 88.36 & 3.19 & 3.75 & 13.77 & 2724 \\
\hline
\end{tabular}

${ }^{1}$ Her bir kilogramında: 4.000.000 IU Vitamin A; 800.000 IU kolekalsiferol (VitD3), 10.000 mg $\alpha$-tokoferil asetat (Vit E); 1.333 mg menadiyon sodyum(Vit K3); 1.000 mg tiyamin monoitrate (Vit B1); $1.667 \mathrm{mg}$ riboflavin(Vit B2); $8.333 \mathrm{mg}$ niasin (Vit B3); $3.333 \mathrm{mg}$ Ca-D-pantotenik asit (Vit B5); $1.667 \mathrm{mg}$ pridoksin (Vit B6); 333 mg folik asit (Vit B9); 5 mg Siyanokobalamin(Vit B12); 15 mg -biotin (Vit H); 16.667 mg Askorbik asit (Vit C);100.000 mg Kolin Klorid; 200 mg Lutein; 12.5 mg Zeaksantin; 26.667 mg Mangan oksit; 20.000 mg Çinko oksit; 20.000 mg Demir sülfat; 1.667 mg Bakır sülfat; 67 mg Kobalt karbonat; 333 mg Kalsiyum İyodat; 50 mg Sodyum Selenit; 300 mg Metiyonin Hidroksi analoğu içermektedir.

${ }^{2}$ DL-metiyonin

${ }^{3}$ TSE (1991)'e göre hesaplandı 

Ortalama yumurta ağırlığı (YA), günlük yem tüketimi (YT), yumurta verimi (YV), yemden yararlanma oran (YYO) ve hasarlı yumurta oranı (HYO) gibi incelenen performans parametrelerine ait değerler 15 günde bir; şekil indeksi (Şİ), kabuk kalınlığı (KK), kırılma mukavemeti (KM), kabuk ağırlığı (KA), sarı indeksi (SI), ak indeksi (AI) ve Haugh birimi (HB) gibi incelenen yumurta kalite kirterlerine ait değerler ise ayda bir yapılan ölçüm ve tartımlarla belirlenmiştir (Kaya and Macit 2012).

Denemenin sonunda her gruptan 6 hayvan olmak üzere toplamda 24 hayvanın kanat altı damarlarından alınan kan örnekleri (yaklaşık $5 \mathrm{ml}$ ), pıhtılaşma aktivatörlü vakumlu tüplere konulduktan sonra soğuk zincir ile laboratuvara getirilip $3000 \mathrm{x}$ g de $5 \mathrm{dk}$ süreyle santrifüj edilerek serumları eppendorf tüplere alınmıştır. Tıp
Fakültesi Biyokimya Anabilim Dalı'nda bulunan Mindray Perfect Plus 400 marka otoanalizör cihazında, kan kolesterol, trigliserid, glukoz, Albumin, AST, ALT, ALP, Ca ve P değerleri ticari kitler kullanılarak (DDS ${ }^{\circledR}$ Spectrophotometric Kits, Diasis Diagnostic Systems Co., İstanbul Turkey) tespit edilmiştir.

Elde edilen verilerin istatistik analizi SPSS 10.0 (1996) paket programı kullanılarak varyans analiz metodu ile gruplar arası farklılığın önemlilik derecesi ise Duncan çoklu karşılaştırma testi ile belirlenmiş̧ir.

\section{Araştırma Bulguları ve Tartışma}

Deneme gruplarının performans parametrelerine ait ortalama değerleri ve varyans analiz sonuçları Çizelge 2'de verilmiştir.

Çizelge 2. Deneme gruplarının performans parametrelerine ait ortalama değerler

\begin{tabular}{cccccc}
\hline GRUPLAR & GYT (g/gün) & YV (\%) & YA (g) & $\begin{array}{c}\text { YYO } \\
\text { (kg yem/ kg yumurta) }\end{array}$ & HYO (\%) \\
\hline K & 118.71 & 91.34 & 66.68 & 1.96 & 0.001 \\
\hline PA & 119.29 & 91.28 & 65.12 & 2.02 & 0.063 \\
\hline FA & 120.57 & 91.48 & 65.55 & 1.99 & 0.143 \\
\hline MA & 118.70 & 91.89 & 66.04 & 2.01 & 0.093 \\
\hline SEM & 2.21 & 1.11 & 0.56 & 0.08 & 0.060 \\
\hline P & 0.932 & 0.980 & 0.235 & 0.821 & 0.406 \\
\hline
\end{tabular}

YA: Yumurta Ağırlığı; YV: Yumurta Verimi; GYT: Günlük Yem Tüketimi; YYO: Yemden Yararlanma Oranı; HYO: Hasarlı Yumurta Oranı;

Yumurtacı tavuk rasyonlarına farklı organik asit (propiyonik, formik, malik) ilavesinin performans özelliklerinden günlük yem tüketimi, yumurta verimi, yumurta ağırlığı, yemden yararlanma oranı ve hasarlı yumurta oranı üzerine anlamlı bir etkisi olmamıştır $(\mathrm{P}>0.05)$. Çizelge 2'de görüldüğü gibi $\mathrm{PA}$ ve $\mathrm{FA}$ deneme gruplarındaki yem tüketimi, $K$ ve $M A$ gruplarından rakamsal olarak daha yüksek bulunmuştur.

$\mathrm{Bu}$ çalışmadan farklı olarak yumurtacı tavuk rasyonlarına farklı seviyelerde organik asit karışımı (propiyonik asit, formik asit ve onların tuzları) ilavesiyle yürütülen bir araştırmada (Yeşilbağ and Çolpan, 2006) yumurta veriminin kontrole göre artırdığı, yemden yararlanma oranının doza bağlı olmamakla birlikte kontrole göre düştüğü ifade edilmiştir. Yine benzer başka bir çalışmada yumurtacı tavuk rasyonlarına kalsiyum propiyonat ilavesinin (Dahiya et al. 2016) yemden yararlanma oranının iyileştiği rapor edilirken, yumurtacı tavuk rasyonlarına değişik seviyelerde propiyonik asit (Oruwari, 1993) ve farklı organik asit karışımlarının ilavelerinin (Kaya et al., 2013; Kaya et al., 2014; Gül et al., 2014) performans parametreleri üzerine anlamlı bir etkiye sahip olmadı bildirilmiştir. Dama (2016) yumurtacı tavuk rasyonlarına değişik seviyelerde (100, 200 ve 300ppm) propiyonik asit ilavesinin yumurta verimini önemli derecede artırdığını rapor etmiştir.

Deneme grupları arasında kabuk kalınlığı hariç diğer incelenen yumurta kalite kriterleri bakımından anlamlı bir farklılığın olmadığı ( $\mathrm{P}>0.05)$ görülmüştür (Çizelge 3). PA grubundaki hayvanlardan elde edilen yumurtalara ait kabuk kalınlığı FA grubundaki hayvanlardan elde edilen yumurtalara ait kabuklardan önemli derecede kalın olduğu saptanmıştır. Organik asitlerin yem katkı maddesi olarak rasyonlara dahil edilmesinin gastrik pH'yı düşürerek pepsinojenin pepsin formuna dönüşümünü hızlandırdığı ve böylece proteinlerin, aminoasitlerin ve minerallerin absorpsiyonu sitimüle ettiği de bildirilmektedir (Park et al., 2009). Organik asitler içerisinde en yüksek pKa değerine propiyonik asit sahip olduğundan dolayı gastrik pH üzerine daha etkili olduğu ve böylece yumurta kabuğunun en önemli minerali olan $\mathrm{Ca}$ absorbsiyonu iyileştirerek yumurta kabuk kalınlığını 
iyileştirdiği düşünülmektedir. Organik asitlerin bağırsak içi pH'sını düşürmek suretiyle rasyondaki Ca absorbsiyonunda iyileşme sağlayarak kabuk kalitesini olumlu yönde etkilediğini bildiren araştırma (Kaya et al., 2014) sonuçlarıyla bu çalışmadan elde edilen bulgular uyum içerisindedir. Kalite kriterleriyle ilgili elde edilen bulgular, daha önce yürütülen çok sayıda araştırma bulgularıyla paralellik göstermektedir (Yesilbağ and Çolpan 2006; Soltan, 2008; Kaya et al., 2015, Dama, 2016).

Çizelge 3. Deneme gruplarının yumurta kalite özelliklerine ait ortalama değerler

\begin{tabular}{cccccccccc}
\hline GRUPLAR & YA (g) & Şi (\%) & $\mathbf{K M}\left(\mathbf{k g} / \mathbf{c m}^{\mathbf{2}}\right)$ & $\mathbf{K K}(\mathbf{m m})$ & KA (g) & SR & Si (\%) & Ai (\%) & HB \\
\hline K & 66.44 & 73.19 & 2.76 & $0.393^{\mathrm{ab}}$ & 8.40 & 12.00 & 42.33 & 9.30 & 86.21 \\
\hline PA & 66.00 & 73.58 & 2.85 & $0.417^{\mathrm{a}}$ & 8.27 & 11.89 & 42.43 & 9.33 & 83.50 \\
\hline FA & 67.55 & 72.36 & 2.35 & $0.388^{\mathrm{b}}$ & 8.36 & 11.89 & 43.09 & 8.46 & 80.49 \\
\hline MA & 67.85 & 73.33 & 2.93 & $0.394^{\mathrm{ab}}$ & 8.64 & 12.00 & 41.38 & 10.03 & 86.07 \\
\hline SEM & 1.03 & 0.54 & 0.21 & 0.01 & 0.14 & 0.17 & 1.44 & 0.43 & 1.77 \\
\hline P & 0.532 & 0.419 & 0.204 & 0.051 & 0.295 & 0.929 & 0.869 & 0.096 & 0.083 \\
\hline
\end{tabular}

a, b : Aynı sütunda farklı harflerle gösterilen ortalamalar arasındaki farklılıklar önemlidir $(\mathrm{P}<0.05)$.

YA: Yumurta Ağırlığı; Şİ: Şekil İndeksi; KM: Kırılma Mukavemeti; KA: Kabuk Ağırlığı; KK: Kabuk Kalınlığı; SR: Sarı Rengi; Sİ: Sarı İndeksi; Aİ: Ak İndeksi; HB: Haugh Birimi

Deneme gruplarının serum kolesterolü (Kol), trigliserit (Tri), glukoz (Glu), Aspartat aminotransferaz (AST), Alkalin fosfataz (ALP), Alanin aminotransferaz (ALT), kalsiyum (Ca) ve fosfor (P) içerikleri ile varyans analizi sonuçları Çizelge 4'te verilmiştir. Kan $\mathrm{Ca}$ ve $\mathrm{P}$ içerikleri hariç incelenen diğer serum parametreleri üzerine grubun anlamlı bir etkisi olmamıştır $(\mathrm{P}>0.05)$. Propiyonik asit içeren grubun ortalama serum $\mathrm{P}$ değeri, formik asit ilaveli gruba oranla daha yüksek olarak saptanırken, serum $\mathrm{Ca}$ düzeyleri PA ve MA gruplarında kontrol grubuna nazaran daha yüksek olarak tespit edilmiştir $(\mathrm{P}<0.05)$.
Yumurtacı tavuklarda \%0.2 düzeyinde organik asit karışımının (\%15 propiyonik asit, \%24 formik asit ve $\% 3$ amonyum hidroksit içeren) (Çetin ve ark. 2006) ve broiler tavuklarda artan seviyelerde asetik asit ilavelerinin (Ur Rehman ve ark. 2016) bazı hematolojik kan parametreleri üzerine önemli bir etkisinin olmadığ 1 bildirilirken, serum $\mathrm{Ca}, \mathrm{P}$, total protein ve Globulin düzeylerinde bir artışın meydana geldiği (Ur Rehman ve ark. 2016) rapor edilmiştir. $\mathrm{Bu}$ araştırmadan elde edilen sonuçlar, çok sayıda çalışma bulgularıyla paralellik göstermektedir (Kaya et al., 2013; Kaya et al., 2015, Dama, 2016).

Çizelge 4. Deneme gruplarının kan parametrelerine ait ortalama değerleri

\begin{tabular}{lllllllll}
\hline GRUPLAR & Kol & Tri & Glu & AST & ALP & ALT & Ca & P \\
\hline K & 133.6 & 1041.8 & 194.6 & 197.8 & 780.6 & 1.40 & $23.64 \mathrm{~b}$ & $3.88 \mathrm{ab}$ \\
\hline PA & 159.8 & 1236.4 & 209.2 & 214.8 & 1064.0 & 1.60 & $25.90 \mathrm{a}$ & $4.82 \mathrm{a}$ \\
\hline FA & 132.4 & 1126.8 & 221.0 & 180.6 & 1006.2 & 1.60 & $24.74 \mathrm{ab}$ & $3.68 \mathrm{~b}$ \\
\hline MA & 132.8 & 1231.6 & 213.0 & 194.4 & 1045.6 & 1.20 & $26.16 \mathrm{a}$ & $3.98 \mathrm{ab}$ \\
\hline SEM & 14.74 & 132.47 & 10.19 & 4.34 & 259.18 & 0.24 & 0.32 & 0.07 \\
\hline P & 0.473 & 0.691 & 0.350 & 0.301 & 0.856 & 0.585 & 0.047 & 0.053 \\
\hline
\end{tabular}

a, b : Aynı sütunda farklı harflerle gösterilen ortalamalar arasındaki farklılıklar önemlidir $(\mathrm{P}<0.05)$.

Kol: Kolesterol (mg/dL); Tri: Trigliserit (mg/dL); Glu: Glukoz (mg/dl); AST: Aspartat aminotransferaz (Unit/L); ALP: Alkalin fosfataz (Unit/L); ALT: Alanin aminotransferaz (Unit/L); Ca: kalsiyum (mg/dl), P: Fosfor (mg/dl)

\section{Sonuç ve Öneriler}

Sonuç olarak, yumurtacı tavuk rasyonlarına değişik organik asit (propiyonik, formik, malik) ilavesinin performans ve yumurta iç kalite özellikleri üzerine önemli bir etkisinin olmaması, dış kalite özelliklerinden kabuk kalınlığı bakımından gruplar arasındaki farkın önemli bulunması ve en yüksek kabuk kalınlığı (0.417 $\mathrm{mm}$ ) ile serum fosfor ve kalsiyum değerlerinin propiyonik asit içeren rasyonla beslenen grupta tespit edilmiş olmasından dolayı yumurtacı tavuk rasyonlarına 200 ppm düzeyinde propiyonik asit ilavesi önerilebilir.

\section{Kaynaklar}

Abdel-Fattah SA, El-Sanhoury MH El-Mednay, N.M. Abdel-Azeem, F, 2008. Thyroid activity, some blood constituents, organs morphology and 
performance of broiler chicks fed supplemental organic acids.Int. J. Poult. Sci., 7: 215-222.

Anonim, 2014. Organik Asitler ve Hayvan Beslemede Organik Asit Kullanımı. http://www.frmtr.com/lisebilgiistekleri/1321725-organik-asitler-ve-kullanimalanlari.html. Erişim tarihi: 01.03.2014.

AOAC, 1990. Official Method of Analysis. Association of Official Analytical Chemists 15th ed., 66-88, Washington, DC.

Çetin N, Çetin E, Kocaoğlu Güçlü B, 2006. Yumurta tavuklarında rasyona ilave edilen humat ve organik asitlerin bazı hematolojik parametreler üzerine etkisi. Ankara Üniv. Vet. Fak. Derg., 53: 165-168.

Dahiya R, Berwal RS, Patil CS, 2016. The effect of dietary supplementation of salts of organic acid on production performance of laying hens. Veterinary World, 9: 1478-1484.

Dama G, 2016. Yumurtacı tavuk rasyonlarına farklı düzeylerde propiyonik asit ilavesinin performans, yumurta kalitesi ve bazı kan parametreleri üzerine etkisi. Ataürk Üniversitesi Fen Bilimleri Enstitüsü (Y.Lisans Tezi), Erzurum.

Gauthier R, 2002. Intestinal health, the key to productivity - the case of organic acids. IASA XXVII convencion ANECA-WPDC. 2002, Puerto Vallarta, Jal. Mexico.

Gül M, Ali TM, Cengiz S, Yildiz A, 2014. Effect of organic acids in diet on laying hens' performance, egg quality indices, intestinal microflora, and small intestinal villi height. Europ. Poult.Sci., 78., DOI: 10.1399/eps.2013.5.

Kahraman Z, Mizrak C, Yenice E, Atik Z, Tunca M, 2009. Yumurta tavuğu rasyonlarında uçucu yağ asidi (uya) kullanımının performans, yumurta kalite kriterleri, organ ağırlıkları, jejenum pH'sı ve kuluçka sonuçları üzerine etkileri. 6. Zootekni Bilim Kongresi, 24-26 Haziran, Erzurum, Tam metinler CD'si, 212-218

Kaya A, Kaya H, Çelebi Ş, 2012. Ruminant hayvanlarda metan üretimini azaltmaya yönelik çalışmalar. Atatürk Üniv. Ziraat Fak. Derg., 43: 197-204.

Kaya A, Kaya H, Gül M, Apaydın B, Timurkaan S, 2015. Effect of different levels of organic acids in the diets of hens on laying performance, egg quality criteria, blood parameters, and intestinal histomorphology. Indian Journal of Animal Research, 49(5), 645-651.

Kaya A, Kaya H, Gül M, Çelebi Ş, 2014. Geç dönemde organik asit ilavesinin yumurtlama performans1, yumurta kalite özellikleri ve bağırsak pH'sı üzerine etkisi. Atatürk Üniv. Ziraat Fak. Derg, 45(1), 15-18.

Kaya H, Kaya A, Gül M, Çelebi Ş, 2013. The effect of zeolite and organic acid mixture supplementation in the layer diet on performance, egg quality traits and some blood parameters. J Anim. Vet. Advances, 12(6): 782-787.

Kaya H, Macit M, 2012. Effect of Inclusion of Garlic (Allium sativum) powder at different levels and copper into diets of hens on performance, egg quality traits and yolk cholesterol content. Int. J. Poult. Sci., 11: 114-119.

Kum E, Kocaoğlu Güçlü B, 2006. Standart ve sıkışık kafes yoğunluğunda yetiştirilen Yumurta tavuğu karma yemlerine organik asit ilavesinin performansa etkisi. Sağlık Bilimleri Dergisi (Journal of Health Sciences), 15(2): 99-106.

Oruwari BM, 1993. Propionic acid and calcium propionate in diets for egg-type layers and broiler chicks. J Appl. Anim. Res., 3:73-81.

Park KW, Rhee AR, Um SJ, Paik IK, 2009. Effect of dietary available phosphorus and organic acids on the performance and egg quality of laying hens. J. Appl. Poult. Res., 18: 598-604.

Soltan MA, 2008. Effect of dietary organic acid supplementation on egg production, egg quality and some blood serum parameters in laying hens. Int $\mathbf{J}$ Poult Sci., 7: 613-621.

SPSS, 1996. SPSS for Windows Release 10.0, SPSS Inc. Chicago.

TSE, 1991. Hayvan yemleri-metabolik (çevrilebilir) enerji tayini (kimyasal metot). TSE No: 9610. Türk Standartları Enstitüsü, Ankara, 1991.

Ur Rehman Z, Ul Haq A, Akram N, El Hack MEA, Saeed M, Ur Rehman S, Meng C, Alaqawany M, Sayab M, Dhama K, Ding C., 2016. Growth performance, intestinal histomorphology, blood hematology and serum metabolites of broiler chickens fed diet supplemented with graded levels of acetic acid. Int. J. Pharmacology, 12:874-883.

Yeşilbağ D, Çolpan İ., 2003. Tüm tane buğday içeren yumurta tavuğu rasyonlarında organik asidin kullanımı, II. Ulusal Hayvan Besleme Kongresi, Bildiriler Kitab1, s.: 270-274. Konya/ Türkiye.

Yeşilbağ, D, Çolpan İ, 2006. Effect of organic acid supplementated diets on growth performance, egg production and quality and on serum parameters in laying hens. Revue. Med. Vet., 157: 280-284. 